\title{
CHANGES OF BLOOD FLOW VELOCITY INDICATING MECHANICAL COMPRESSION OF THE VERTEBRAL ARTERIES DURING ROTATION OF THE HEAD IN THE NORMAL HUMAN MEASURED WITH TRANSCRANIAL DOPPLER SONOGRAPHY
}

\author{
SANDRO ROSSITI*, REINHARD VOLKMANN* *
}

SUMMARY - The dynamical changes of blood flow velocity of the intracranial vertebral arteries (VA's) and proximal basilar artery (BA) provoked by rotation of the head in normal volunteers were measured using pulsedwave transcranial Doppler sonography (TCD). In another group both VA's were examined simultaneously with 2-channel TCD. Blood flow velocities diminished compared to the neutral position in all vessels, independently of the side. Total obstruction of the flow was not observed. Our findings reveal a definitive decrease of blood flow velocity at the vertebrobasilar artery system provoked by rotation of the head in normal humans. This physiological phenomenon is suggested to have an impact on the cerebral blood flow in patients with impaired autoregulation of the cerebral vessels, low volume flow reserve in the contralateral VA or insufficient collateral channels because of normal anatomical variation, especially those patients under general anesthesia or comatose.

KEY WORDS: basilar artery, cerebrovascular disorders, hemodynamics, intraoperative care, posture, stroke, transcranial Doppler sonography, ultrasonics, vertebral artery, vertebrobasilar insufficiency.

Alteraçzes da velocidade do fluxo sanguíneo indicativas de compressão mecánica das artérias vertebrais durante rotação da cabeça registradas com Doppler transcraniano

RESUMO - Estudos anatômicos, angiografias em voluntários normais e relatos clínicos de pacientes com sintomas atestam o fato de que o fluxo sanguíneo através das artérias vertebrais (VA's) $\epsilon$ parcialmente obstruido ao nível da articulaçāo atlanto-axial (C1-C2) durante a rotação da cabeça. Variaçōes anatômicas das artérias cerebrais basais, trauma e outros processos patológicos têm sido relacionados à compressão mecânica fisiológica das VA's na patogenia de insuficiência vertebrobasilar. No presente estudo, as alterações dinâmicas da velocidade do fluxo sanguíneo (BFV) nas artérias do sistema vertebrobasilar, provocadas por rotação da cabeça em voluntários adultos normais, são medidas com Doppler transcraniano (TCD). Material e métodos: 30 voluntários adultos (grupo 1) foram examinados com TCD das VA's (segmento intracraniano V4) e artéria basilar (BA). Em 8 individuos o estudo foi repetido com um instrumento de TCD de dois canais, permitindo o estudo simultâneo das VA's (grupo 2). A artéria basilar foi examinada com a técnica transforaminal e as VA's com o método transoccipital. Resultados: A BFV na BA e VA's diminuiu de modo significante durante rotaçâo da cabeça no grupo 1 , independentemente do lado da rotaçăo ( $\mathbf{p} \leq 0.001$ ). A mais acentuada diminuição do BFV ocorreu na VA do lado direito durante rotaçæo ipsilateral (-18\%). Alteraçóes semelhantes foram notadas no grupo 2. Todavia, nesse grupo as alteraçбes da BFV na VA do lado esquerdo não foram significantes $(p=0.08)$, tanto a rotação ipsilateral quanto à contralateral. Comentários: A análise da relação entre a velocidade média do fluxo sanguíneo em dada artéria (V-média), a BFV medida com TCD (i.e. o componente máximo dos vetores de velocidade de fluxo no centro da artéria), o fluxo sanguíneo volumétrico e o fluxo sanguíneo cerebral regional (rCBF), sugere que a magnitude da diminuiçăo da BFV registrada no presente estudo não reflete uma diminuição proporcional

*Department of Clinical Neurosciences, Section of Neurosurgery, Göteborg Univeristy; and **Department of Clinical Physiology. Sahlgrenska University Hospital, Göteborg, Sweden.

Sandro Rossitti, MD - Department of Clinical Neurosciences, Section of Neurosurgery, Göteborg University Sahlgrenska University Hospital - S-413 45 Göteborg - Sweden. 
do rCBF, devido a existência de fluxo sangứneo colateral do sistema arterial carotídeo (via artéria comunicante posterior) e, também, devido à possibilidade de que as alteraçōes pós-estenóticas do fluxo sanguíneo interferem na relaçăo entre BFV e V-média. Todavia, o presente estudo corrobora observaçōes anteriores que sugerem ser a compressåo mecânica das VA's ao nível C1-C2 um fen6́meno presente no ser humano normal. A compressão das VA's pode assumir proporçōes críticas para o rCBF vertebrobasilar em pacientes com variaçōes anatômicas ou com patologia oclusiva resultantes em compartimentalizaçäo do rCBF (i.e. casos em que a VA comprimida É funcionante como vaso terminal), em pacientes com distúrbio da auto-regulaçăo da circulação cerebral ou com reduzida reserva cerebrovascular (e.g. pacientes com trauma crânio-encefálico e hipertensão intracraniana), especialmente pacientes comatosos ou sob anestesia geral.

PALAVRAS-CHAVE: artéria basilar, doença cerebrovascular, hemodinâmica, cuidado intra-operatório, postura, icto, sonografia, Doppler transcraniano, ultrassom, artéria vertebral, insuficiência vertebrobasilar.

Perturbation of blood flow in the cerebral arteries provoked by changes in the position of the head is a physiological phenomenon worth studying and quantifying because of its medical and ergonomic implications. Rotation of the head may impair the blood flow in the vertebral artery (VA) along its passage through the atlanto-axial region (Fig 1). This phenomenon has been observed during perfusion of the vertebral arteries and angiography in the cadaver, and on angiography in healthy volunteers ${ }^{15}$, as well as in studies in normal volunteers with transcranial Doppler ultrasonography (TCD) ${ }^{9,18,19}$. Stroke or recurrent symptoms of vertebrobasilar insufficiency have been related to the physiological compression of the VA in the presence morphological particularities of the basal cerebral arteries, such as hypoplasia of one VA combined with inadequate collateral flow from the carotid arteries, trauma and other disease processes ${ }^{4,7,14,18,19,21-23}$. Particularly tragic is
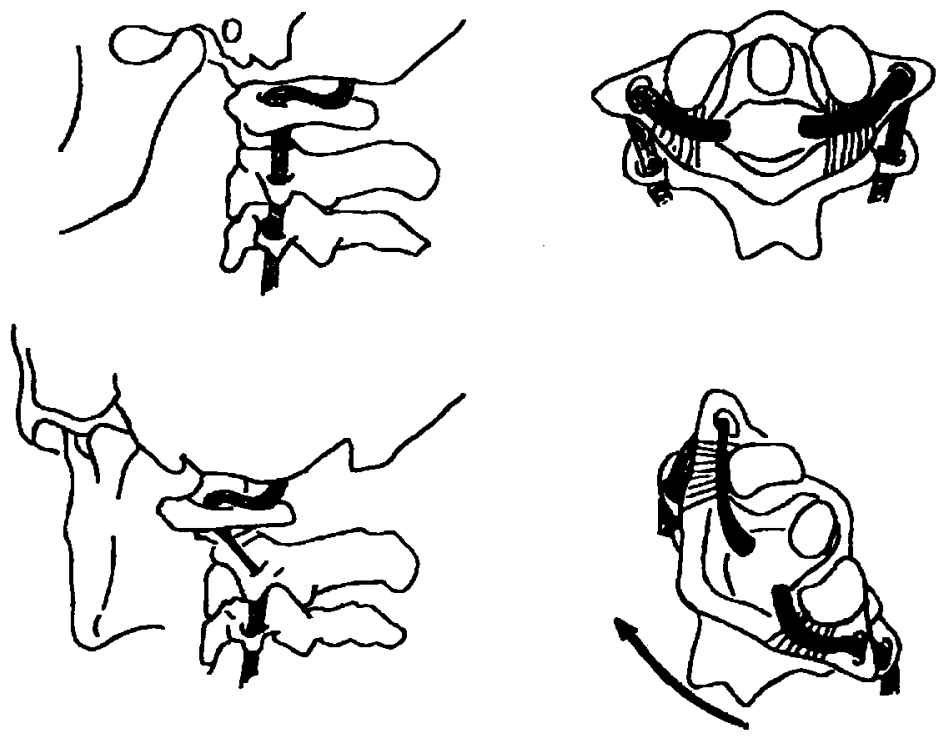

Fig I. The vertebral artery is fixed as it courses along the posterior portion of the lateral mass of the atlas (C:1), but is relatively mobile and curved between $C: 1$ and the transverse foramen of the axis (C:2). This is probably a functional adaptation to the extreme spinal motility at the $C: 1-C: 2$ region, where the axial movement is in average $47^{\circ}$ (range $22^{\circ}-58^{\circ}$ ). In spite of the motility, the vertebral artery may be stretched, drawn medially and compressed against the lateral mass of $C: 1$ during rotation of the head's. The figure is partially redrawn from Dahl et al. ${ }^{6}$ and Shimizu et al. ${ }^{23}$. 


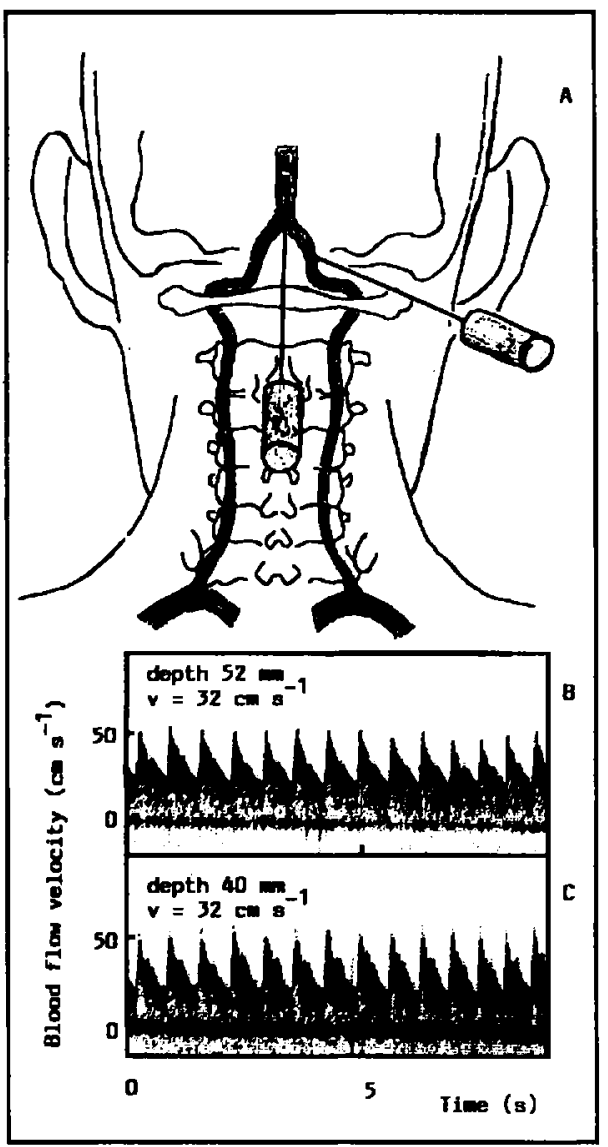

Fig 2. Schematic representation of the anatomical landmarks for the paramedian transoccipital approach and for the transforaminal approach for transcranial Doppler ultrasonography of the vertebral and basilar arteries (a). The figure also shows simultaneous $T C D$ of the left vertebral artery with the transforaminal (b) and the paramedian transoccipital (c) techniques in a normal volunteer. The insonation angle for the VA is probably the same in both approaches because the same blood flow velocity has been regularly recorded by simultaneous examination of the same VA with both methods. Such was the case in this example. However, different values of TCD parameters (i.e. flow velocities and pulsatility indices) may be provoked by methodological variation, because these methods involve vessel insonation at different depths and the ultrasound beam is directed through structures of different attenuation requiring different gain adjustments. The insonation angle is possibly somewhat wider for the $B A$ in the paramedian approach, as we have found regularly lower BA flow velocities with the transoccipital approach. the ocurrence of vertebrobasilar stroke in patients under general anesthesia due to surgical positioning ${ }^{11}$, and in previously neurologically intact young patients during chiropractic cervical manipulation ${ }^{6.12,13}$.

In this study we measured the dynamical changes of blood flow velocity of the vertebrobasilar artery system provoked by rotation of the head in the normal human. The intracranial VA's and proximal basilar artery (BA) were examined with one-channel TCD; the VA's were also examined simultaneously with two-channel TCD. This study may have implications for head positioning of comatose patients in intensive care units and surgical positioning of patients under general anesthesia.

\section{MATERIAL AND METHODS}

\section{TCD techniques for examination of the} vertebrobasilar circulation:

Midline transforaminal approach ${ }^{1,5,30}$ : The patients bows the head forward, toward the chin down to the chest. In this way the occipito-atlantal space widens. The TCD probe is positioned midline in the suboccipital region inferior to the median nuchal crest (Fig 2), and directed toward the bridge of the nose. The initial search for signals can be made with the sample volume placed at a depth of $60-70 \mathrm{~mm}$. The proximal and middle segments of the $\mathrm{BA}$, and the intracranial VA's are located by changing the insonation depth, by swepping the probe to both sides and by moving the probe slightly inferiorly when scanning the median and distal BA segments. The insonation depths vary with the thickness of the soft tissues of the neck.

Transoccipital paramedian approach ${ }^{18,20}$ : This technique permits a complete examination of the intracranial VA's and BA without moving the patient from the supine position, what may be of value in intensive care conditions ${ }^{16}$. Blood flow velocity and flow direction in these vessels are registered through the occipital bone at relatively more superficial levels, and identification of right and left vertebral arteries usually represents no problem. The ultrasound instrument must be adjusted to higher gain than in the transforaminal approach, and the signal/noise ratio is similar in to the one obtained transtemporally in the anterior circulation. The TCD probe is positioned $20 \mathrm{~mm}$ posterior to the mastoid apex (Fig 2). The initial insonation depth is $30 \mathrm{~mm}$, which is increased in 2 mm steps until the VA is localized at its course around the posterior arch of the atlas and into the foramen 
magnum, usually $40 \mathrm{~mm}$ deep. The VA is then followed along its intracranial portion by increasing the insonation depth. Optimization of the signal at deeper regions is obtained by displacing the probe postero-infero-medially, in direction to the thinnest part of the occipital bone, situated about $3 \mathrm{~cm}$ lateral to the midline, behind the center of the foramen magnum. The junction of the VA's is found about $60 \mathrm{~mm}$ deep. The BA and the contralateral VA are identified at deeper regions. As with the transforaminal approach, the insonation depths vary with the thickness of the soft tissues of the neck.

\section{Data collection and analysis:}

Group 1: Thirty normal adult volunteers (18 men and 12 women), aged $37.3 \pm 12.9$ years (SD) were examined with TCD of the VA's and BA in the neutral position and during maximal rotation of the head to both sides. Blood flow velocities (BFV) were recorded with a pulsed-wave Doppler instrument with low frequency (2 MHz) ultrasonic signal (TC 2000, Eden Medical Electronics, Uberlingen, Germany). BFV is expressed in $\mathrm{cm}^{-1}$. The TCD examinations were carried out with the subjects in the sitting position. They were asked to produce the maximal possible rotation of the head at every occasion. The volunteers were asked to close the eyes during the examination because BFV in the posterior cerebral arteries (i.e. the terminal branches of the BA) increase in response to light stimulation ${ }^{2}$. The midline transforaminal approach was used for the proximal BA (depth 72-84 $\mathrm{mm}$ ) and the transoccipital approach for the intracranial VA's (depth $\$ 2-58 \mathrm{~mm}$ ).

Group 2: Eight volunteers from Group 1 were also examined with 2-channel TCD for simultaneous insonation of the VA's (ultrasound instrument: Multi Dop X, DWL, Sipplingen, Germany).

The statistical methods were paired two-tailed t-test at the $5 \%$ level of the null hypothesis (Group 1 ) and Wilcoxon non-parametric test (Group 2).

\section{RESULTS}

In the Group 1, the time-averaged BFV of the outline of the Doppler spectrum in the VA's and BA diminished significantly as compared to the neutral position, independently of the vessel or the side (Table 1). The dynamic changes during head rotation could not be registered because of

Table 1. Blood flow velocities in the vertebrobasilar artery system of normal volunteers before and after rotation of the head $(N=30)$.

\begin{tabular}{llcll}
\hline Artery & Position & Blood flow velocity $(\mathrm{cm} / \mathrm{s})$ & SD & $\begin{array}{l}\text { Significance of the } \\
\text { changes from the } \\
\text { neutral position }\end{array}$ \\
BA & Neutral & 42.9 & 9.6 & \\
BA & Rotation to R & 39.4 & 8.9 & $\mathrm{p}=0.001$ \\
BA & Rotation to L & 39.3 & 9.3 & $\mathrm{p}<0.001$ \\
Right VA & Neutral & 43.5 & 8.1 & \\
Right VA & Ipsilateral rotation & 29.3 & 7.5 & $\mathrm{p}<0.001$ \\
Right VA & Contralateral rotation & 30.9 & 8.3 & $\mathrm{p}<0.001$ \\
Left VA & Neutral & 33.5 & 8 & \\
Left VA & Ipsilateral rotation & 28.7 & 8 & $\mathrm{p}<0.001$ \\
Left VA & Contralateral rotation & 29.3 & 7.6 & $\mathrm{p}<0.001$ \\
\hline
\end{tabular}

Table 2. Blood flow velocities in the vertebral arteries of normal volunteers before and after rotation of the head measured simultaneously with 2-channel TCD $(N=8)$.

\begin{tabular}{lllll}
\hline Position & $\begin{array}{l}\text { BFV in the right } \\
\text { vertebral artery } \\
\text { (mean } \pm \mathrm{SD} \text { ) }\end{array}$ & $\begin{array}{l}\text { Significance of the } \\
\text { changes from the } \\
\text { neutral position }\end{array}$ & $\begin{array}{l}\text { BFV in the left } \\
\text { vertebral artery } \\
\text { (mean } \pm \text { SD) }\end{array}$ & $\begin{array}{l}\text { Significance of the } \\
\text { changes from the } \\
\text { neutral position }\end{array}$ \\
$\begin{array}{l}\text { Neutral } \\
\text { Rotation to } \mathrm{R}\end{array}$ & $35.6 \pm 2.3$ & & $38.1 \pm 4.8$ & \\
Rotation to $\mathrm{L}$ & $31.3 \pm 1.9$ & $\mathrm{p}=0.01$ & $31.9 \pm 2.7$ & $\mathrm{p}=0.03$ \\
$\mathrm{p}=0.02$ & $33.0 \pm 2.3$ & $\mathrm{p}=0.08$ \\
\hline
\end{tabular}




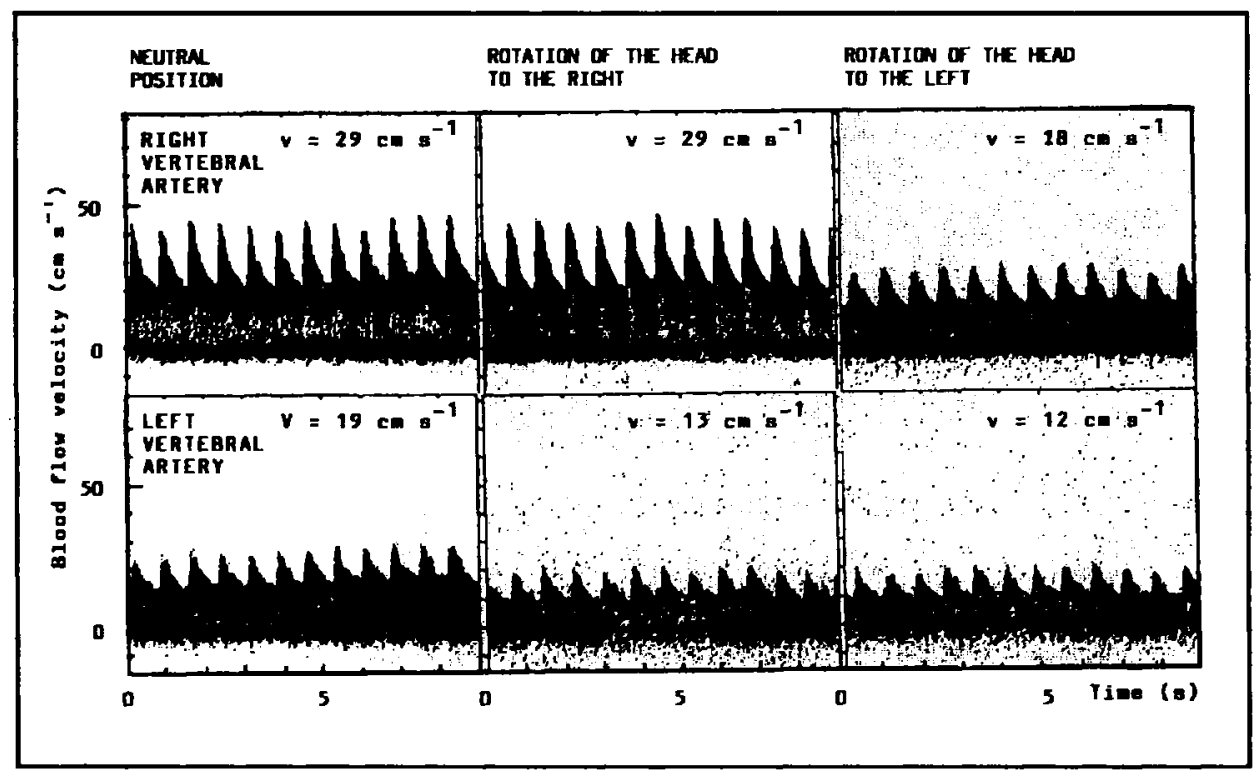

Fig 3. Patient (female, aged 53) with symptomatic mechanical compression of the vertebral arteries on rotation of the head to the lefi, when she presents with dizziness.

diminishing or loss of the Doppler spectrum due to the free-hand technique. The ultrasound beam was repositioned after every head movement in almost every case. Thus the occurrence of a transient hyperemic response on returning to the neutral position could not be verified.

Similar changes were observed in Group 2 (Table 2), except on turning of the head to the left side, by which BFV changes in the left VA were not significant $(\mathrm{p}=0.08)$. BFV at the VA's did not differ significantly on ipsilateral and contralateral head rotation. In no case obstruction of the flow was observed.

Dynamic TCD examination of a patient with symptomatic compression of the VA on head rotation is presented in Fig 3.

\section{COMMENTS}

The angle between the ultrasonic beam and the insonated VA probably was the same in consecutive measurements at the same depth from the same site before and after head rotation. The paramedian suboccipital approach used for VA insonation ${ }^{20}$ is less dependent on thickness of the neck's soft tissues than the midline transforaminal approach. The VA was examined in a neutral anteroposterior position, with some contralateral head tilt. BA ultrasonography is more difficult after changes in head position. Ventroflexion of the head and neck was necessary for BA insonation with the transforaminal approach. Thus comparison of the BA flow velocities before and after head rotation may have been influenced by changes of insonation angle. Diminishing or loss of the Doppler spectrum occurred during head rotation due to the free-hand technique. Repositioning of the transducer was done according to anatomical reference points (i.e. the midline, the inion and the mastoid apex) and by obtaining the highest Doppler shift. As a consequence, the dynamic changes during head rotation and whether a transient hyperemic response occurred on returning to the neutral position could not be registered. Insonation of the extracranial VA at the subclavian fossa reveals a similar diminishing of BFV during head rotation (R. Volkmann: unpublished data). 
TCD findings in patients with symptomatic mechanical compression of the VA have been reported by Fujioka et al ${ }^{7}$, with emphasis on the effect of head rotation in BFV through the posterior cerebral arteries. Transient BFV increases at the BA and posterior cerebral arteries after returning to the neutral position were recorded by Brautaset ${ }^{4}$ in two patients with symptomatic bilateral vertebral artery compression. Such a response is similar to the transient hyperemia in the ipsilateral middle cercbral artery after brief cervical carotid artery compression, which has been suggested to be a qualitative indicator of cerebral autoregulation ${ }^{8}$.

Sakai et al..$^{21}$ observed in a patient, using single-proton emission tomography, diminished regional cerebral blood flow in the left cerebellum and right occipital lobe during an atack of vertebrobasilar insufficiency, which was provoked by turning of the head to the left.

Takahashi et al. ${ }^{27}$ performed vertebral angiography with contralateral rotation of the head $\left(80^{\circ}-90^{\circ}\right)$ on 15 patients without vertebrobasilar disease, and observed that in some cases the VA was stretched at the atlantoaxial level, but not complete occlusion was observed. Takahashi et al. ${ }^{27}$ speculate that occlusion of the VA on head rotation is not a normal phenomenon. In earlier reports (reviewed by Rossitti ${ }^{15}$ ) complete unilateral occlusion has been observed even in normal volunteers.

Since the presentation of our preliminary results ${ }^{18,19}$, Hedera et al. ${ }^{9}$ reported changes of BFV in the BA after extreme rotation of the head in a group of 58 normal volunteers. Significant reduction of the mean BFV within the BA was observed when the VA's presented flow velocity asymmetry higher than $75 \%$ due to head rotation ipsilateral to the presumably hypoplasic VA.

Physiological variables such as BFV present apparently unpredictable spontaneous oscillations, i.e. TCD blood flow velocities are not constant over time. Rossitti et al. ${ }^{17}$ studied time series of the axial blood flow velocity at the middle cerebral artery in the normal human to characterize its temporal heterogeneity. They concluded that the BFV fluctuations are self-similar over a wide range of time intervals and with two different time scales, with relatively low fractal dimension. In the present study, some discrepancy of sequential examinations due to the irregular time course of the BFV cannot be excluded. However, the constancy of BFV diminution during head rotation in almost every observation $(\mathrm{N}=30)$ is hardly a random phenomenon.

The question arises, whether the observed impairment of BFV in the vertebrobasilar artery system reflects a correponding diminution of the regional cerebral blood flow (rCBF). This problem was analyzed in detail by Rossitti et al..$^{18}$ using the model of Sorterberg et al ${ }^{24}$ to estimate relative changes of $\mathrm{rCBF}$ and BFV in consecutive measurements. Some controversy exists whether the timeaveraged maximum flow velocity (expressed in $\mathrm{cm} / \mathrm{s}$ ) can be used to estimate volumetric blood flow (measured in $\mathrm{ml} / \mathrm{s}$ ), especially under conditions of rapidly changing blood flow rate and blood pressure ${ }^{10}$. The insonation angle and vessel area at the sample volume may remain constant during head rotation, but changes of the perfusion territory due to collateral blood flow from the carotid artery system and changes of the parabolic flow velocity profile are expected.

Has the physiological mechanical compression of the VA's implications for surgical positioning of patients under general anesthesia? The effects of surgical positioning on $\mathrm{rCBF}$ has to our knowledge not been investigated. This question may particularly be relevant in neurosurgery, where surgical positioning of the patient is an important moment of every operative procedure, because of the need for precise localization of deep surgical targets, minimally invasive exposures and often prolonged procedures. Extreme degrees of ventroflexion, dorsal extension and rotation of the neck are often a prerequisite for "ideal" surgical positioning ${ }^{25.23}$. It is good practice to test the tolerance of the awake patient to surgical positioning when planing elective surgery ${ }^{27,28}$. Ischemia and infarction are rare but severe complications of chiropractic manipulation of the cervical spine $e^{6,12,13}$, by which dissection of the vessel wall or traumatic arterial spasm may be provoked. Understanding the dynamical anatomy 
of the neuroaxis and associated structures ${ }^{15}$ may prevent unexpected and undesireble results. In addition, the effects of pressure areas, traction points and systemic hemodynamic compromise are accentuated under anesthesia ${ }^{28.29}$.

\section{CONCLUSIONS}

Our findings suggest a definitive decrease of blood flow velocity in the vertebrobasilar artery system provoked by rotation of the head in the normal human. In spite of the fact that TCD blood flow velocities are proportional to blood flow rate in most circumstances $3,8,18,24$, the magnitude of BFV decrease probably does not reflect a proportional decrease in the rCBF, due to collateral flow from the carotid artery system and to post-stenotic changes in the velocity profile. However, physiological compression of the VA on head rotation may influence rCBF in patients with inefficient collateral blood flow channels, impaired cerebral autoregulation or low cerebrovascular reserve, especially in patients under general anesthesia or comatose.

\section{REFERENCES}

1. Aaslid R. Transcranial Doppler examination techniques. In Aaslid R (ed) Transcranial Doppler Sonography. Wien: Springer-Verlag, 1986, p 39-59.

2. Aaslid R. Visually evoked dynaminc blood flow response of the human cerebral circulation. Stroke 1987, 18: 771-775.

3. Aaslid R, Newell DW, Stooss R, Sorterberg W, Lindegaard K-F. Assessment of cerebral autoregulation dynamics by simultaneous arterial and venous transcranial Doppler. Stroke 1991, 22: 1148-1154.

4. Brautaset NJ. Provokable bilateral vertebral artery compression diagnosed with transcranial Doppler. Stroke 1992, 23: 288-291.

5. von Büdingen HJ, Staudacher T. Die Identifizierung der Arteria basilaris mit der transkraniellen DopplerSonographie. Ultraschall 1987, 8: 95-101.

6. Dahl A, Bjark P. Anke IM. Cerebrovasculaere komplikasjoner til manipulasjonsbehandling av nakken. Tidsskr Nor Laegeforen 1982, 102: 155-157.

7. Fujioka KA, Ernsberger AM, Nichols SC, Spencer MP. Transcranial Doppler assessment of mechanical compression of the vertebral arteries. J Vasc Technol 1991, 15: 254-259.

8. Giller CA. A bedside test for cerebral autoregulation using transcranial Doppler ultrasound. Acta Neurochir (Wien) 1991, 108: 7-14.

9. Hedera P, Bujdáková J. Traubner P. Blood flow velocities in basilar artery during rotation of the head. Acta Neurol Scand 1993, 88: 229-233.

10. Kontos HA. Validity of cerebral arterial blood flow calculations from velocity measurements. Stroke 1989 , 20: $1-3$.

11. Langmayr JJ, Buchberger W, Birbarnmer G. Ischämische Läsionen im Vertebralisstromgebiet als seltene Komplikation der lumbalen Diskuschirurgie. Neurochirurgia (Stuttgart) 1993, 36: 164-166.

12. Malm J, Olsson T. Cervikal manipulation - är det verkligen försvarbart? Läkartidningen 1992, 89: 1992.

13. Nielsen AA. Cerebrovasculaere insulter foraarsaget af manipulation af columna cervicallis. Ugeskr Laeger 1984, 146: 3267-3270.

14. Roche L, Colin M, De Rougemont J, Verdine J, Vitni C, Tommasi M. Lésions traumatiques de la colonne cervicale et atteintes de l'artère vertébrale: responsabilité d'un examen médical. Ann Med Lég 1963, 43: 232-235.

15. Rossitti S. Biomechanics of the pons-cord tract and its enveloping structures: an overview. Acta Neurochir (Wien) 1993, 124: 144-152.

16. Rossitti S, Jakobsson K-E, Johansson A, von Essen C. Survival and recovery after ring fracture of the skull base. Upsala J Med Sci Suppl 1993, 52: 62.

17. Rossitti S, Stephensen H. Temporal heterogeneity of the blood flow velocity at the middle cerebral artery in the normal human characterized by fractal analysis. Acta Physiol Scand 1994, 151: 191-198.

18. Rossitti S, Volkmann R, Löfgren J. Changes of blood flow velocity in the vertebrobasilar circulation during rotation of the head in the normal human. Biomechanics Seminar 1992, 6: 92-99.

19. Rossitti S, Volkmann R, Löfgren J. Mechanical compression of the vertebral arteries during rotation of the head in the normal human: a Doppler study. 44th Annual Meeting of the Scandinavian Neurosurgical Society, Tampere, Finland, June 10-13, 1992: abstr 59.

20. Rossitti S, Volkmann R, Stephensen H. The transoccipital approach for transcranial Doppler ultrasonography of the vertebrobasilar circulation. Neurochirurgia (Stuttgart) 1993, 36: 148-150. 
21. Sakai F, Ishii K, Igarashi H, Suzuki S, Kitai N, Kanda T, Tazaki Y. Regional cerebral blood flow during an attack of vertebrobasilar insufficiency. Stroke 1988, 19: 1426-1430.

22. Sherman DG, Hart RG, Easton JD. Abrupt change in head position and cerebral infarction. Stroke 1981, 12: $2-6$.

23. Shimizu T, Waga S, Kojima T, Niwa S. Decompression of the vertebral artery for bow-hunter's stroke: case report. J Neurosurg 1988, 69: 127-131.

24. Sorterberg W, Lindegaard K-F, Rootwelt K, Dahl A, Russell D, Nyberg-Hansen R, Nomes H. Blood velocity and regional blood flow in defined cerebral artery systems. Acta Neurochir (Wien) 1989, 97: 47-52.

25. Sugita K. Microneurosurgical Atlas. Berlin: Springer-Verlag, 1985.

26. Symon L (ed). Operative surgery: neurosurgery. Ed 3. London: Butterworths, 1979.

27. Takahashi I, Kaneto S, Asaoka K, Handa T. Rotational occlusion of the vertebral artery at the atlantoaxial joint: is it truly physiological? Neuroradiology 1994, 36: 273-275.

28. Tew JM Jr, Scodary DJ. Supratentorial procedures: basic techniques and surgical positioning. In Apuzzo MJL (ed). Brain surgery: complication avoidance and management. New York: Churchill Livingstone, 1993, Vol 1, p 31-50.

29. Tew JM Jr, Scodary DJ. Infratentorial procedures: surgical positioning. In Apuzzo MJL (ed). Brain surgery: complication avoidance and management. New York: Churchill Livingstone, 1993, Vol 2, p 1609-1620.

30. Volc D, Possnigg G, Grisold W, Neuhold A. Transcranial Doppler sonography of the vertebro-basilar system. Acta Neurochir (Wien) 1988, 90: 136-138. 